\title{
THE CONTENT AND PIGMENT COMPOSITION OF Sargassum crassifolium J.Agardh ON SEVERAL DRYING TREATMENTS
}

\author{
Windu Merdekawati ${ }^{1 *}$, Leenawaty Limantara ${ }^{2}$ and AB. Susanto ${ }^{3}$ \\ ${ }^{1}$ Magister of Biology, Satya Wacana Christian University, Salatiga, Jawa Tengah 50711 \\ ${ }^{2}$ Ma Chung Research Center for Photosynthetic Pigments, Ma Chung University, Malang 65151 \\ ${ }^{3}$ Faculty of Fisheries and Marine Science, Diponegoro University, Tembalang, Semarang 50275 \\ *e-mail: winz.merdekawati18@gmail.com
}

\begin{abstract}
S. crassifolium J.Agardh is one of the brown seaweed species which is abundant and widespread in Indonesian waters. This species of brown seaweed has been used as a source of food and medicine, one of them is in the form of alginates. So far, the common process of manufacturing alginates eliminates a lot of the pigment in that seaweed. S. crassifolium J.Agardh is rich in various types of pigments that have benefits for health. This type of seaweed has chlorophyll $a$ and fucoxanthin as its dominant pigment. The aim of this research is to determine the content and composition of the pigment of S. crassifolium J.Agardh on fresh and drying treatment. The drying treatment includes open air sun drying (SD), dehumidifier, and solar tunnel dryer (STD). Pigment identification process is carried out by the method of thin layer chromatography (TLC), spectrophotometer and high performance liquid chromatography (HPLC). Analysis of the pigment content was carried out by the method based on the theory of Maeda et al. (2005) using HPLC. Based on the results of the research on the fresh extract of $S$. crassifolium J.Agardh, several types of pigment and their percentage are obtained, which are: chlorophyll $a$ (68.37\%); fucoxanthin $(20.68 \%)$ and xantophyll $(10.95 \%)$. On the drying process, xantophyll and fucoxanthin were increased, on STD (16.17\% and $28.96 \%)$; SD (21.34\% and $43.43 \%)$; dehumidifier (15.98\% and $34.07 \%)$. The drying process also causes the formation of pheophytin on STD and SD treatments which are $48.09 \%$ and $35.32 \%$ respectively, as well as the increment of xantophyll content.
\end{abstract}

Keyword: drying treatment, pheophytin, S. crassifolium, xanthophyll.

\section{Introduction}

The current food crisis was the focus of discussion in every forum in the world. Food crisis is a crucial issue because the food is a primary requirement for human survival. As stated in the Universal Declaration of Human Right 1948, Article 25 Paragraph (1) UDHR says, "Everyone has the right to a standard of living adequate for the health and well-being of himself and of his family, including food....."

Based on the information of the world food agency (FAO), food crisis is happening right now is the greatest global crisis throughout the $21^{\text {st }}$ century. Because of the food crisis, at this time around 1 billion or 963 million starving people in the world. The number has increased compared to the year 2008 that is counted 915 million inhabitants (FAO, 2009).

In dealing of food crisis, every country has a specific strategy to one that is exploring alternative sources of food from the sea. Indonesian waters have a high biodiversity that is a great potential. One of the marine organisms that can be used as food is seaweed. Seaweed can be used as food and medicines (Burtin, 2003; Takamatsu, 2003; Fitton, 2005). One type of seaweed, which has a content of bioactive compound, is Sargassum. Brown seaweed are common in Indonesia, grew up in sheltered waters and big waves on the rocky habitat (Atmadja et al., 1996). They have a variety of chemical composition and pigment, including iodine, protein, vitamin $\mathrm{C}$, minerals and phenol compounds. Sargassum have various pigment, i.e. chlorophyll $a$, chlorophyll $c, \beta$-carotene, xanthophylls, violaxanthin, fucoxanthin, flavoxanthin, neoxanthin A and B (Yunizal, 2004; Lee, 2008).

So far, Sargassum only consumed by people who live in coastal areas. Generally, they consume this marine plant in fresh or as pickle vegetables. Fresh seaweed cannot be stored longer at room temperature, so that must be processed into dry form. The common process of manufacturing seaweed eliminates a lot of the pigment content, whereas pigments are known health benefits, such as a source of antioxidant (Lim, 2002; Shanab, 2007; Patra, 2008), anticancer (Chernomorsky et al., 1999), antiobesity (Maeda et al., 2005), and anti tumour (Nakamura, 1996). 


\section{Materials and Methods}

\section{Sample preparation}

The samples collected from Awur Bay, Jepara. They were transported to the faculty laboratory by using the cooler container. Samples were cut by lab knife manually after that all of them were completely washed in seawater. Samples were rinsed in the distilled water and then they were drained. Thus, both sand and other sections containing unwanted substances were removed. Samples were dried with several drying process i.e. solar tunnel dryer, open-air sun drying and dehumidifier.

Water content was calculated using the following formula (Sudarmaji, 1996):

$$
\text { water content }(\%)=\frac{\text { initial weight }(g)-\text { final weight }(g)}{\text { initial weight }(g)} \times 100 \%
$$

\section{Extraction of pigments}

Fresh and dried samples were ground into small pieces. $50 \mathrm{~g}$ of sample was extracted with acetone/methanol $3: 7(\mathrm{v} / \mathrm{v})$ with a ratio of sample to solvent was 1:10 (w/v). Filtrate was filtered and then partitioned with diethyl ether. Filtrate were dried with nitrogen gas (Britton et al., 1995).

\section{Thin Layer Chromatography (TLC)}

Dry pigment were dissolved in dietyl ether and spotted on the silica gel plate $(4 \times 10 \mathrm{~cm})$. Allow the TLC plate to develop (separation of pigments) for approximately 10 minutes in chamber with a mobile phase of hexane/ether/acetone $(6: 3: 2 \mathrm{v} / \mathrm{v} / \mathrm{v})$. Remove the TLC plate from the chamber when the solvent front is approximately $1.0 \mathrm{~cm}$ from the top of the TLC plate. The rate at which a pigment moves up the plate is reported as an $R_{\mathrm{f}}$ value which is defined as the ratio of the distance moved by the spot to the distance moved by the solvent. Determine the $R_{\mathrm{f}}$ values for each of the pigments you observe using the formula provided below.

$$
R_{f}=\frac{\text { distance moved by solute }(\text { pigment })}{\text { distance moved by solvent }}
$$

\section{Ultraviolet and Visible (UV - Vis) Spectrophotometry}

UV - vis absorption of pigment dissolved in acetone $100 \%$ was recorded in a spectrophotometer Varian Cary 50 at a wavelength of $350-800 \mathrm{~nm}$ (Jeffrey et al., 1997).

\section{Pigment content analysis}

Content of pigments were analyzed by high performance liquid chromatography (HPLC) Shimadzu LC$20 \mathrm{AB}$ with ODS reversed phase coloumn $\mathrm{C}_{18}, 5 \mu \mathrm{m}, \varnothing 4 \times 25 \mathrm{~mm}$ in a mobile phase methanol/acetonitrile with a ratio of 7:3 (v/v). Detection performed at wavelength from 190 to $800 \mathrm{~nm}$ with flow rate $1 \mathrm{~mL} / \mathrm{min}$ and pressure of 1000 psi (Maeda et al., 2005).

\section{Result and discussion}

Analysis of the pigment content was carried out by the method based on the theory of Maeda et al (2005) using HPLC. HPLC has the ability to analyze the pigment and their derivatives accurately. This method can be used in pigment analysis both qualitative and quantitative. Type of mobile phase determines the success of the separation of pigments. In this study we use more polar solvent.

According to the chromatogram in Figure 1, there is a shift in the peak and the formation of new peak in the chromatograms of pigment S.crassifolium on the dry treatment. At the intervals (0-10) minutes, there are several peaks shifting pigment after the drying process. They were detected at the retention time i.e. 3.99; 4.35; 4.97, and 5.88. There is also a new peak in pigment extracts of the solar tunnel dryer (STD) and dehumidifier which detected at the retention time 2.45 and 2.89. At the intervals (15-60) minutes is only seen a few peaks in the fresh or dried extract. They were detected at the retention time 20.95; 30.10 and 43.86. Formation of a new peak in the chromatogram is probably due to degradation processes. Chlorophylls have the most important characteristic with their extreme lability. They are sensitive to light, heat, oxygen, and chemical degradation (Gross, 1991).

For futher analysis, identification of pigment were analyze by the spectra pattern of each pigment. Figure 2 show the absorption of spectra with the details of the maximum absorbance as listed in Table 1. 


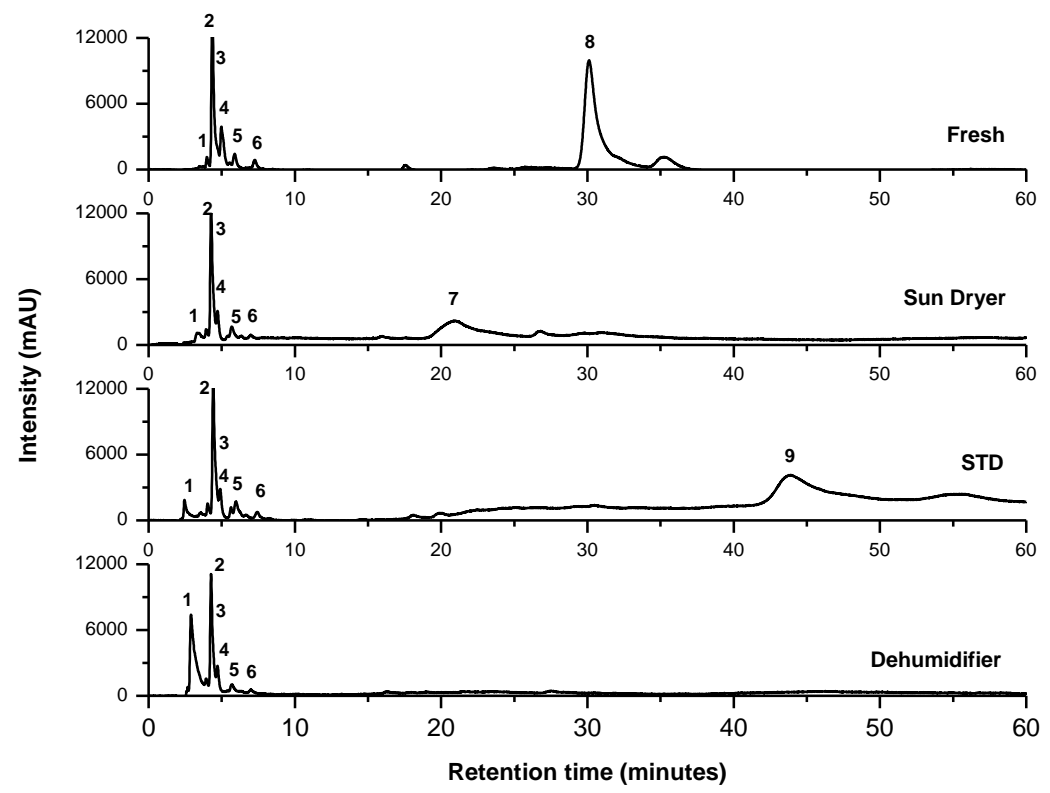

Figure 1. Chromatogram of pigment extracts of S.crassifolium on fresh and dry treatments at $420 \mathrm{~nm}$.
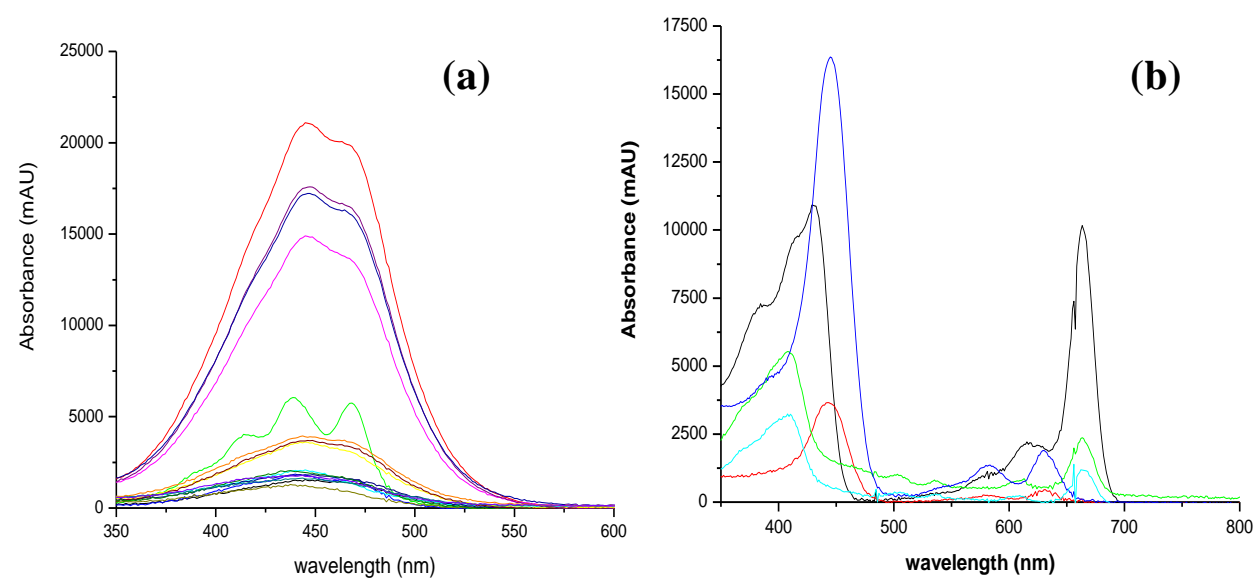

Figure 2. Absorption spectra of (a) carotenoid and (b) chlorophyll and derivatives.

Table 1. The composition of extract pigment of fresh and dry $S$. crassifolium

\begin{tabular}{|c|c|c|c|c|c|c|c|}
\hline \multirow[b]{2}{*}{ Peak } & \multicolumn{4}{|c|}{ Retention time (minutes) } & \multirow{2}{*}{$\begin{array}{c}\text { Absorbance } \\
\text { maxima } \\
(\mathbf{n m})\end{array}$} & \multirow{2}{*}{$\begin{array}{c}\text { Absorbance } \\
\text { maxima } \\
\text { (Reference) }\end{array}$} & \multirow[b]{2}{*}{ Pigment } \\
\hline & Fresh & Dehumidifier & SD & STD & & & \\
\hline 1 & - & - & - & 2.45 & $445,581,629$ & 445,581,629 (Jeffrey et al., 1997) & Chlorophyll derivative \\
\hline 2 & - & 2.89 & - & - & $445,581,629$ & 445,581,629 (Jeffrey et al., 1997) & Chlorophyll derivative \\
\hline 3 & 3.99 & 3.92 & 3.93 & 4.03 & 440,462 & 442,465 (Taylor et al., 2006) & Xantophyll \\
\hline 4 & 4.35 & 4.26 & 4.27 & 4.41 & 445 & 446 (Jeffrey et al., 1997) & Fucoxanthin \\
\hline 5 & 4.97 & 4.71 & 4.71 & 4.89 & 446,463 & 443,465 (Taylor et al., 2006) & Xantophyll \\
\hline 6 & 5.88 & 5.68 & 5.67 & 5.97 & 438 & 439 (Banora et al., 2000) & Xantophyll \\
\hline 7 & - & - & 20.95 & - & $408,608,666$ & 409,608,666 (Jeffrey et al., 1997) & Pheophytin $a$ \\
\hline 8 & 30.10 & - & - & - & $431,621,664$ & $431,618,665$ (Jeffrey et al., 1997) & Chlorophyll $a$ \\
\hline 9 & - & - & & 43.86 & $409,613,663$ & $409,608,666$ (Jeffrey et al., 1997) & Pheophytin $a$ \\
\hline
\end{tabular}


Based on the area of peak, we can analysis the percentage of pigment content on each dry treatment. The results of the analysis presented in Figure 3.

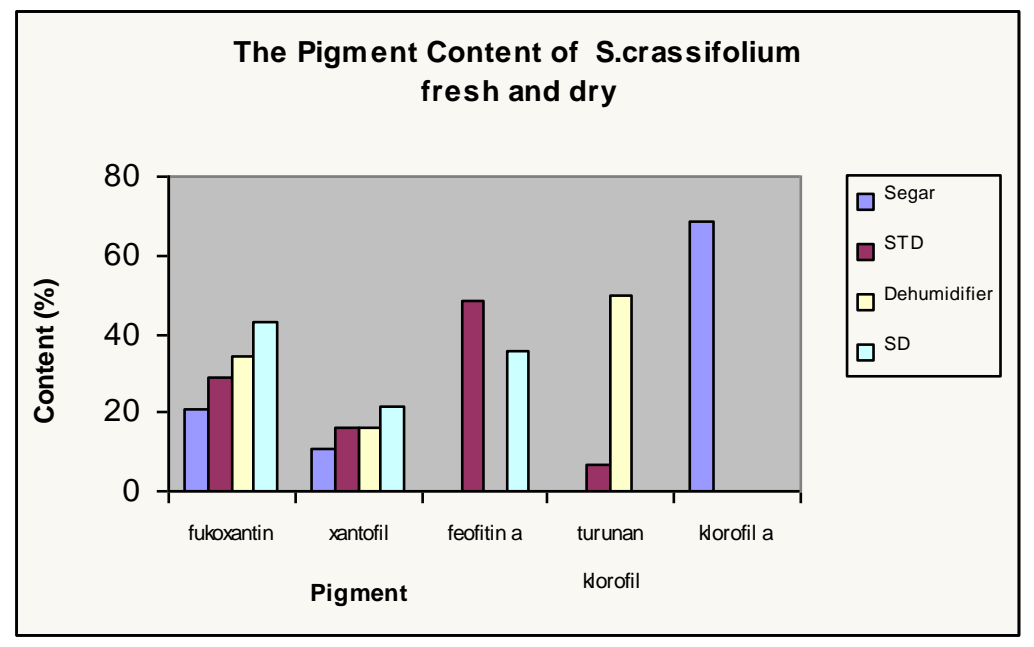

Figure 3. The result of the analysis of pigment content of fresh S.crassifolium and several drying treatments [STD, dehumifier, and open sun drying (SD)]

Based on Figure 3 shows that the extract of S.crassifolium there are some pigments in the percentage i.e. chlorophyll $a(68.37 \%)$, fucoxanthin $(20.68 \%)$, and xantophylls $(10.95 \%)$. In some drying methods showed the pigment compositions, which consist of fucoxanthin, xantophylls, pheophytin and other derivate of chlorophyll. On the drying methods with open air sun drying (SD), the content of each pigment i.e. 43.34\%; $21.34 \% ; 35.32 \%$. In this methods we did not find any chlorophyll derivate instead pheophytin.

On the drying methods with solar tunnel dryer (STD), there are several pigments i.e. fucoxanthin (28.96\%), xantophyll (16.17\%), pheophytin $a(48.09 \%)$ and derivatives of chlorophyll (6.78\%). Furthermore, the drying method with dehumidifier there are some pigments in their respective content i.e. fucoxanthin $(34.07 \%)$, xantophyll (15.98\%), and chlorophyll derivatives (49.95\%).

The analysis of pigment content and composition, showed that the extract of fresh S.crassifolium contains chlorophyll $a$ and fucoxanthin as the dominant pigment, with total content i.e. $20.68 \%$ and $68.37 \%$. This fact is in accordance with the results of Hegazi (2006) which states that chlorophyll $a$ and fucoxanthin is the dominant pigment of Sargassum sp. The result of HPLC also showed that fucoxanthin and xantophyll are relatively stable during the drying process compared with the chlorophyll, they are presents in all treatments. The differences of the content of xantophyll during the drying process, presumabely because this pigment is very vulnerable to light, thus leading to isomerisation and oxidation are strongly influenced by temperature, time of drying and drying techniques (Gross, 1991).

We did not find any chlorophyll on the extract of S.crassifolium on the drying treatments. This fact is due to the nature of chlorophyll $a$ that very unstable so easily degraded into their derivatives. Degradation of chlorophyll can be derived either in vivo (natural) or in vitro (in laboratory). Natural transformation occurs during the biosynthesis of chlorophyll produced in large quantities and some of its derivatives in a number of relatively small, laboratory transformation occurs when chlorophyll had some treatments, amon others exposed to light, heat,dry, salt and storage in long periods or the addition of compound, such as acid and alkali (Gross, 1991). During processing (drying treatment), plant material containing chlorophyll will have a change or loss of pigment (Gross, 1991). Discoloration was caused by the presence of Mg dechelatase enzyme that can breakdown the macrocyclic rings. Furthermore, the activity of enzyme will hydrolyzes the phytyl ester group of chlorophylls and pheophytins, giving rise to chlorophyllides and pheophorbides, respectively (Minguez-Mosquera et al., 1989).

\section{Conclusion}

Based on results, it can be concluded that chlorophyll $a$ and fucoxanthin are the dominant pigments of fresh S.crassifolium. On the drying process, chlorophyll degrades into pheopythin and several other chlorophyll derivatives, while the other fucoxanthin and xantophyll are relatively stable pigment of the drying process. 


\section{Acknowledgments}

Windu Merdekawati is grateful to The Department of National Education for the research funds of Beasiswa Unggulan Programme at Magister of Biology, Satya Wacana Christian University.

\section{References}

(2009). www.fao.org

Atmadja, W. S., A. Kadi, Sulistijo dan R. Satari. 1996. Pengenalan Jenis-Jenis Rumput Laut Indonesia. Jakarta : Puslitbang Oseanologi-LIPI.

Bonora, A., Pancaldi, S., Gualandri, R., and Fasulo, M. 2000. Carotenoid and Ultrastructure Variations in Plastids of Arum italicum Miller Fruit During Maturation and Ripening. Ferrara. Italy. Journal of Experimental Botany, Vol, 51, No. 346. pp.873-884.

Britton, Liaaen-Jensen, and Pfander. 1995. Carotenoids Analysis and Isolation. Vol 1A. Berlin : Birkhauser.

Burtin, P. 2003. Nutritional Value of Seaweed. Electronic Journal of Environmental, Agricultural and Food Chemistry 2(4) : 498-503

Chernomorsky, S., Segelman, A. and Porets, R. D. 1999. Effect of dietary chlorophyll derivatives on mutagenesis and tumor cell growth. Teratog Carcinog Mutagen, 19(5): 313-322. Sciences.

Fitton, H. 2005. Marine Algae and Health : A Review of The Scientific and Historical Literature.http:/www.glycosciene.org/glycoscience/document_viewer.wv?FILENAME=CO2

Gross, J. 1991. Pigment in Vegetables : Chlorophylls and Carotenoids. New York : Van Nostrand Reinhhold.

Hegazi, M. I. 2006. Separation, identification and quantification of photosynthetic pigments from three Red Sea seaweeds using reverse-phase high performance liquid chromatography. Egyptian Journal of Biology, 4: $1-6$.

Jeffrey, S.W., R.F.C. Mantoura., S.W.Wright. 1997. Phytoplankton pigments in oceanography:guidelines to modern methods. Unesco.

Lee, R. E. 2008. Phycology. Fouth Edition. Cambridge University Press. http:/www.cambridge.org/97805621864084

Lim, S. N., Cheung, P. C. K., Ooi, V. E. C., and Ang, P.O. 2002. Evaluation of antioxidative activity of extracts from a brown seaweed, Sargassum siliquastrum. Journal of Agriculture and Food Chemistry, 50: $3862-$ 3866. http://www.icm.cuhk.edu.hk/icm/en/research/research02.pdf.

Maeda, H., Masashi, H., Tokutake, S., Katsura, F., and Kazuo Miyashita. 2005. Fucoxanthin from edible seaweed, Undaria pinnatifida, Shows Antiobesity effect Through UCP1 Expression in White Adipose Tissues. Biochemical and Biophysical Research Communications. Japan, P : 392-397.

Minquez-Mosquera, M., Garrido-Fernandez, J. dan Gandul-Rojas, B. 1989. Journal of Agriculture of Food Chemistry: Pigments Changes in Olive During Fermentation and Brine Storage. Vol. 37 : 8-11.

Nakamura, T. 1996. Antioxidant activity of phlorotannin isolated from the brown alga Eistenia bicyclis. Fisheries Science 62(6) : 923-926.

Patra, J. K., Rath, S. K., Jena, K., Rathod, V. K., and Thatoi, H. 2008. Evaluation of antioxidant and antimicrobial activity of seaweed (Sargassum sp) extract: a study on inhibition of glutathione-Stransferase activity. Turkish Journal Biology, 32: 119 - 125. http://drs.nio.org/drs/bitstream/2264/1075/ 1/Turk-J-Biol-32-119.pdf.

Shanab, S.M.M. 2007. Antioxidant and antibiotic activities of some seaweeds (Egyptian isolates). International Journal of Agriculture and Biology, 9 (2): 220-225. $\quad$ http://www.fspublisher.org/ journal/199.pdf.

Sudarmadji, S., Bambang Haryono dan Suhardi. 1989. Analisa Bahan Makanan dan Pertanian. Pusat Antar Universitas Pangan dan Gizi Universitas Gajah Mada. Penerbit Liberty. Yogyakarta, 172 hal.

Takamatsu, S., Hodges, T. W., Rajhbandari, I., Gerwick, W. H., Hamann, M. T., Nagle, D.G. 2003. Marine Natural Product as Novel Antioxidant Prototypes. Journal of Natural Product. 66: 605-608

Taylor, K. L., Brackenridge, A. E., Vivier, M. A., Oberholster, A. 2006. High Performance Liquid Chromatography Profiling of the Major Carotenoids in Arabidopsis thaliana Leaf Tissue. South Africa. Journal of Cromatography A, 1121 (2006) 83-91.

Wang, B. J., Zer R. Y., and Lucy Sun Hwang. 1995. Quantitative Analyses of Chlorophylls and Their Derivatives by Thin Layer Chromatography. Journal of The Chinese Agricultural Chemical Society. Inc : $11 \mathrm{pp}$.

Yunizal. 2004. Teknologi Pengolahan Alginat. Pusat Riset Pengolahan Produk dan Sosial Ekonomi Kelautan dan Perikanan. BRKP, Jakarta, 66 hlm. 
